\title{
Interpreting the Viking Age to Medieval Period Transition in Norse Orkney through Cultural Soil and Sediment Analyses
}

\author{
Ian A. Simpson, ${ }^{1, *}$ James H. Barrett, ${ }^{2}$ and Karen B. Milek ${ }^{3}$ \\ ${ }^{1}$ School of Biological and Environmental Sciences, University of Stirling, \\ Stirling FK9 4LA, Scotland, United Kingdom \\ ${ }^{2}$ Department of Archaeology, The King's Manor, University of York, York YO1 \\ rEP, United Kingdom \\ ${ }^{3}$ Department of Archaeology, University of Cambridge, Downing St., Cambridge \\ CB2 3DZ, United Kingdom
}

\begin{abstract}
The transition from the Viking Age (ca. A.D. 800-1050) to the Medieval period (ca. A.D. 1050-1500) saw the development of widening trade activities that incorporated peripheral North Atlantic polities into mainstream Europe and contributed to the intensification of marineresource exploitation and agricultural production in these localities. As yet, there is only limited understanding of these intensification processes and their interrelationships, particularly at a local, site-based level. Through the micromorphological analysis of cultural soils and sediments at Quoygrew, Westray, Orkney, we explore the characteristics of farming and fishing activity during the Viking Age-Medieval transition period and establish their chronological relationships. The study demonstrates: (1) that intensification took place from ca. A.D. 966-1162 on an already existing Viking Age settlement, (2) that intensification of fishing activity occurred prior to the intensification of arable agriculture, and (3) that the Quoygrew site continued throughout this period as an economically diverse permanent settlement. When viewed in a wider North Atlantic context, these findings indicate that intensification of different economic activities proceeded at different rates and that intensification of specialized economic activities during the transition from the Viking Age to the Medieval period was dependent on existing knowledge of local environments. (C) 2005 Wiley Periodicals, Inc.
\end{abstract}

\section{INTRODUCTION}

The period of political, economic, and social transformations that marked the transition from the Viking Age (ca. A.D. 800-1050) to the Medieval period (ca. A.D. 1050-1500), traditionally commencing ca. A.D. 1050, is a watershed in northern European history. It has been characterized primarily as a period of transition from decentralized, chieftain-based authorities with pagan ideology to centralized state authorities in which Christian ideology was dominant. This process included the onset of Scandinavian state formation and the incorporation of "peripheral" North Atlantic polities, such as northern Norway, Iceland, Orkney, and Shetland into new state structures (Barrett et al., 2000a; Figure 1). With these new political and social

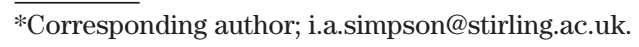

Geoarchaeology: An International Journal, Vol. 20, No. 2, 357-379 (2005)

(C) 2005 Wiley Periodicals, Inc.

Published online in Wiley Interscience (www.interscience.wiley.com). DOI:10.1002/gea.20054 


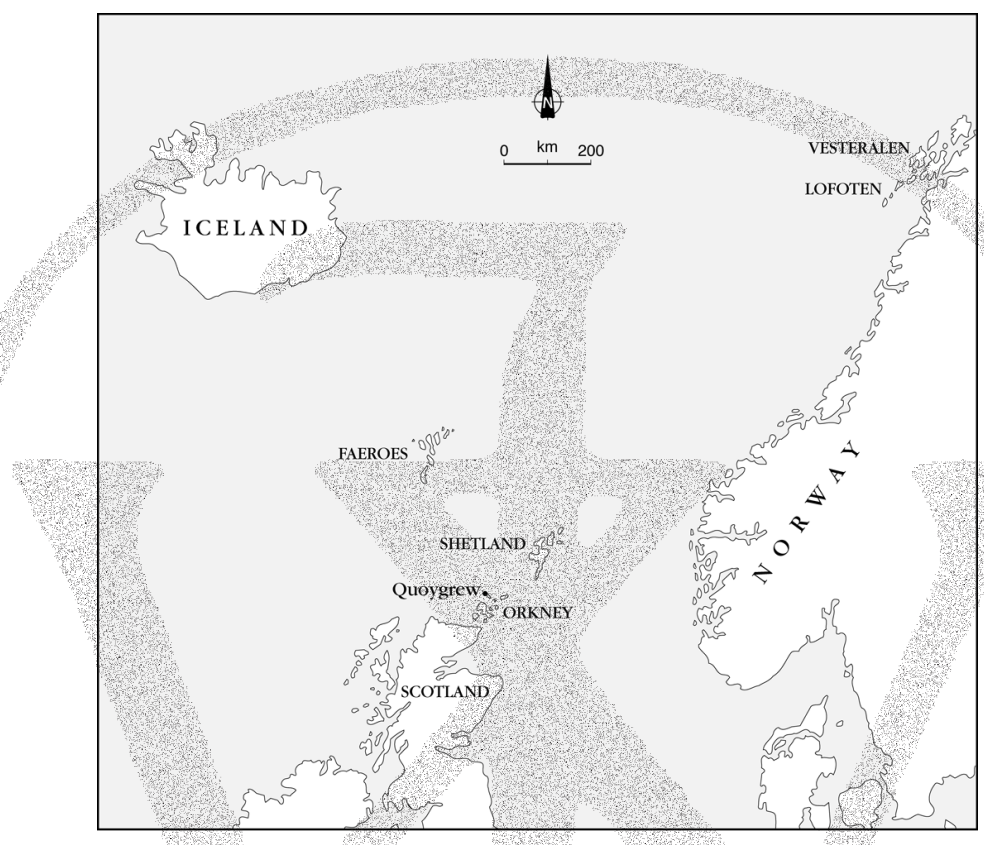

Figure 1. Orkney and Quoygrew in a North Atlantic setting.

conditions came the acceleration of long-range market trade of utilitarian products, including dried fish and grain, and the associated intensification of marine-resource exploitation and agricultural production. Although precise time scales for these intensification processes and their relative significance in different localities continues to be debated, there is no doubt that new economic relationships between "peripheries" and "cores" emerged during this period (e.g., Urbanczyk, 1992; Helle, 1993; Barrett, 1997; Barrett et al., 2000a; Andersson, 2002). Geoarchaeological investigations of cultural soils and sediments have made significant contributions to the understanding of this important period in the peripheral North Atlantic polities. These investigations have included defining the onset of intensive semispecialized fishing activity, the position of farming in the transition economy, and the land-management characteristics of intensive arable production (see, for example, Davidson et al., 1986; Simpson and Barrett, 1996; Simpson, 1997; Simpson et al., 2000).

Geoarchaeological investigations of this transition in North Atlantic polities have yet to assess the extent to which fishing, farming, and their intensification were interdependent, particularly at the site level. One focus for this type of investigation is the site of Quoygrew on the island of Westray, in the former Norse earldom of Orkney and Caithness (Figure 1). This site, dated to the Viking Age and Medieval period, has extensive fish-midden deposits, a small farm mound, and raised anthropogenic soils. These site attributes, with their range of cultural soils and sediments, provide the opportunity to consider interrelationships between fishing and farming 
activities in one locality. The objectives of this paper are, therefore, to establish a chronological framework for the cultural soils and sediments at Quoygrew, to characterize the attributes of the cultural soils and sediments, and to interpret these data in terms of economic activities and organization. Thin-section micromorphology, supported by conventional bulk-soil analyses, and associated radiocarbon dates are integrated to characterize the cultural deposits at Quoygrew. These techniques have already been successfully applied to cultural soils and sediments across the North Atlantic region, and provide information about sediment source, variability of composition, the physical relationship between organic, mineral, and anthropogenic components, post-depositional disturbances, and soil-formation processes within defined time scales (Davidson and Simpson, 2001). As a result of this geoarchaeological study, a new understanding of site-scale intensification of economic practices in Viking Age to Medieval period Orkney is beginning to emerge.

\section{The Site}

The coastal site of Quoygrew (HY 443506 ) lies at the northern margin of a large northwest-facing bay, Rackwick, in a township of the same name in Westray, Orkney (Figure 2). The site is occupied by the ruins of a modern croft, abandoned in the 1930s, and overlies an irregular mound ca. $2 \mathrm{~m}$ in elevation and ca. $50 \mathrm{~m}$ in diameter (Area G). This mound overlooks a second low mound on the shore, which has been sectioned by coastal erosion (Area A). Fish middens and structures exposed in this wave-cut bank were first recorded in 1978 , when a test pit at the site resulted in the recovery of a bone pin, suggesting a Viking Age or Late Norse date (Colley, 1983). The site was called Nether Trenabie in 19th-century sources (Miller, 1866), a name that incorporates the boer element (Old Norse) traditionally associated with early and high-status Norse estates (Marwick, 1952; Thomson, 1995). Field-name evidence, "North Tun," suggests a tunmal (Old Norse) adjacent to the site, indicating land permanently held by the early farmstead, and generally subject to intensive manuring and arable cultivation (Clouston, 1922; Thomson, 1987; Simpson, 1997).

\section{METHODS}

\section{Sampling Techniques}

Previous hand-auger surveys indicated substantial volumes of midden material underlying the modern croft, and a ca. $8 \times 6 \mathrm{~m}$ area (Area G1) was excavated on the southern edge of this mound. The maximum depth to subsoil was $1.6 \mathrm{~m}$; the top $0.3-0.7$ $\mathrm{m}$ is composed of turf and homogenized soil under which lay undisturbed midden deposits. These were finely stratified, with the field stratigraphy divided into two distinct zones or "blocks": an upper block containing predominantly fish bone and a lower block containing predominantly mammal bone (Figure 3). An extension of this trench (Area G2) also permitted examination of stratigraphic relationships between these deposits and surrounding anthropogenic raised soils (see below; context G025; Figure $3)$. Six undisturbed samples were collected in Kubiena tins $(8 \times 5 \times 4 \mathrm{~cm})$ for micro- 


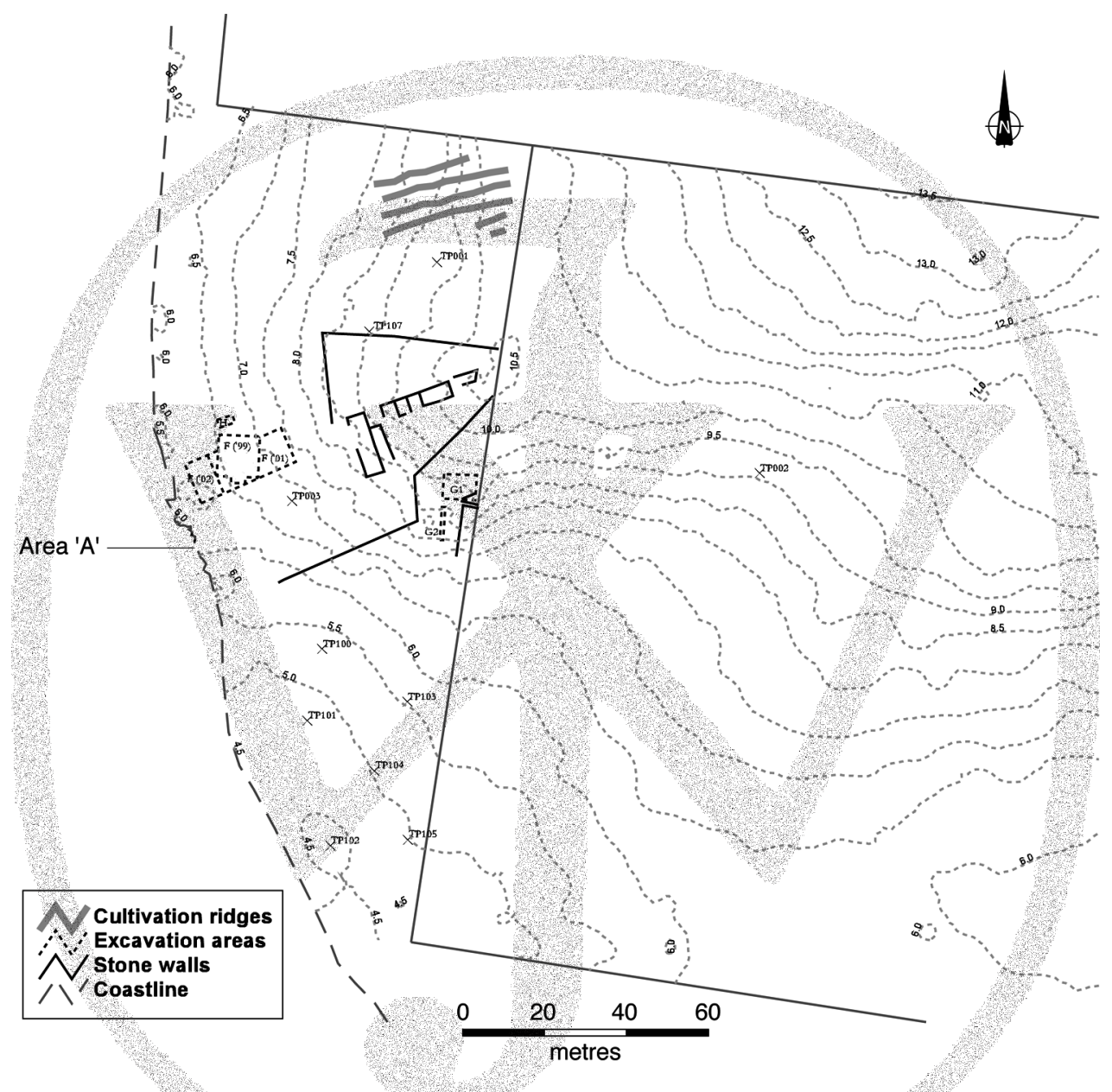

Figure 2. Plan of the Quoygrew site, showing the excavation areas and test pits. The fish midden is evident as a slight mound at the coast. The farm mound occupies the western terminus of an east-west-oriented ridge.

morphological analysis, together with samples for bulk analyses. Two samples of bone material (pig skull and horse pelvis) and two cereal grains from the overlying raised soils (obtained by wet sieving) were used for radiocarbon measurement in this area.

Auger survey also identified anthropogenic raised soils with occasional black, peaty flecks adjacent to Area G. Two profiles were exposed in the raised soils, one east of Area G, where the soils were at their thickest and one north of the mound, where soils were less thick (TP002 and TP001, respectively; Figure 4). Undisturbed, representative samples from these profiles were collected in Kubiena tins, along with parallel bulk samples: Five samples came from profile TP002 and three from profile TP001. Two cereal grains and a fragment of burnt peat obtained from a wetsieved sample from profile TP002 were used for radiocarbon measurement. 


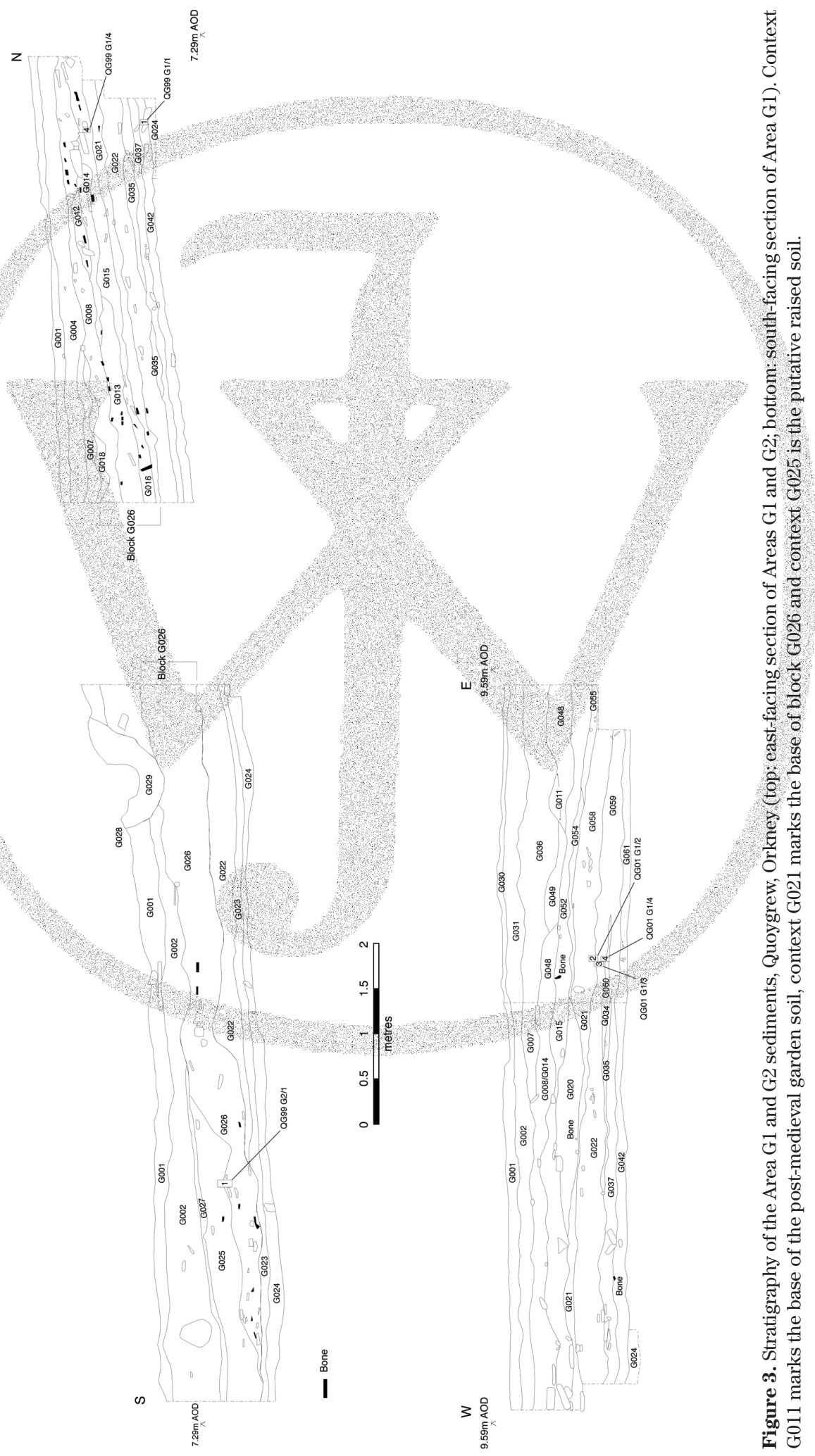




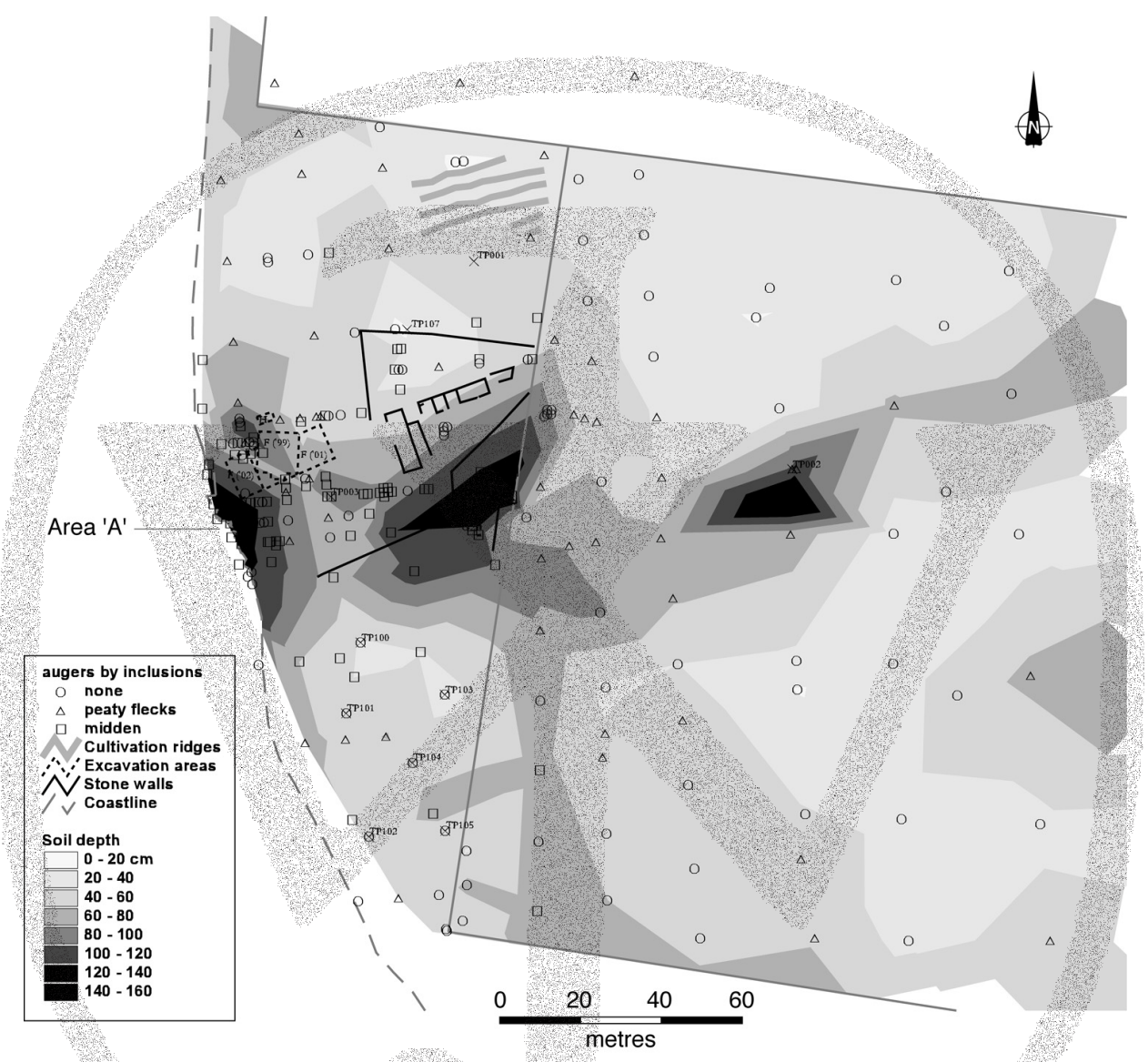

Figure 4. Soil and midden thickness around Quoygrew based on auger survey. The fish midden and farm mound are evident as deep anthropogenic sediments with frequent bone and shell inclusions. The raised soils appear as thickened deposits, sometimes exhibiting occasional black peaty flecks. Windblown sand horizons are excluded from these results (after Zimmermann, 2001).

An extensive cliff-side survey revealed that the wave-cut cultural deposits, with substantial volumes of fish-bone material, extended for ca. $40 \mathrm{~m}$ along the shore (Area A). One sample column (column A) was chosen for geoarchaeological investigation because it preserved the cliff-edge midden to a greater depth $(1.5 \mathrm{~m})$ and was less disturbed by cliff-edge slumping. The column measured $50 \times 50 \times 150 \mathrm{~cm}$, and seven undisturbed samples for micromorphological analysis were collected in Kubiena tins from its north-facing section, together with small bulk samples (Figure 5). Sampling included 18 out of the 27 layers and lenses that had been identified in the field, and was designed to ensure the maximum range of deposit types. Thirteen samples of cereal grain, derived from wet sieving of sediments, and two samples of mammal bone material were used for radiocarbon measurement. 


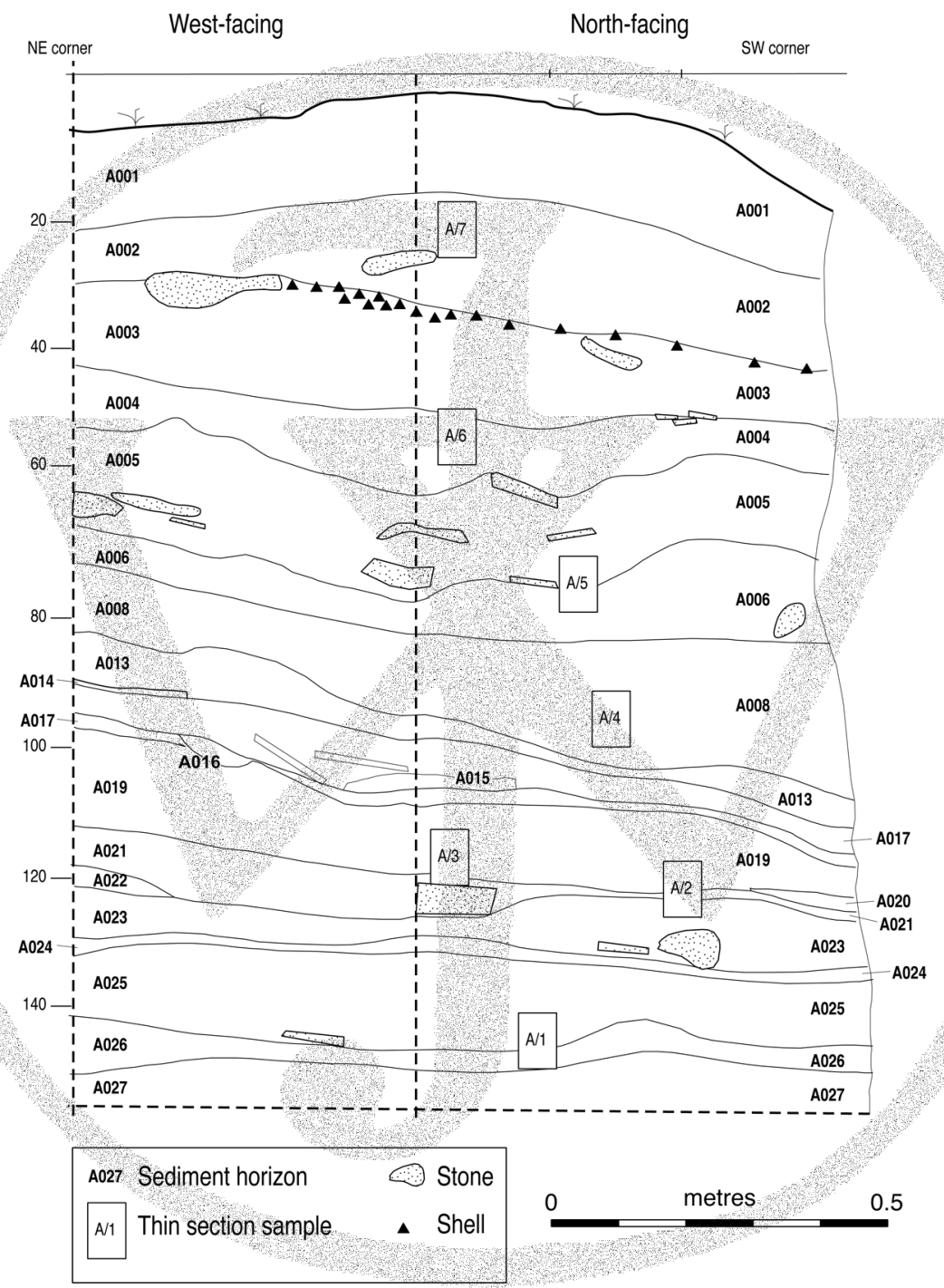

Figure 5. Stratigraphy of the Area A sediments, Quoygrew, Orkney.

\section{Laboratory Analyses}

Thin sections were prepared following standard procedures at the University of Stirling Thin Section Micromorphology Laboratory (http://www.thin.stir.ac.uk/methods.htm), and included acetone exchange of water, resin impregnation under vacuum, cutting, and precision lapping to $30 \mu \mathrm{m}$. Thin sections were described using petrological microscopes $(\times 10-\times 400$ magnification with a range of light sources $)$ following 
internationally accepted terminology (Bullock et al., 1985; Stoops, 2003), with descriptions recorded in semiquantitative tables. Interpretation of the observed features rests upon the evidence of a number of workers, notably Courty et al. (1989) and FitzPatrick (1993), together with peat-ash reference materials collected in Caithness and Orkney.

Bulk-soil samples were air-dried and passed through a 2-mm sieve. Subsamples were analyzed for their particle-size distribution, total carbon, total phosphorus, and $\mathrm{pH}$. The particle-size distribution was determined by sieving and sedimentation, using an Andreason pipette after pretreatment with $\mathrm{H}_{2} \mathrm{O}_{2}$ to remove organic carbon, and after dispersion by shaking in Calgon <zaq; $1>$ for 8 hours. Total organic carbon was determined by Micro-Dumas combustion analysis (Carlo Erba Analyser) with complete flash combustion of the sample and analysis of the resultant gases by gas chromatography, total phosphorus by acid-persulfate digestion of the soil sample, followed by colorometric analysis (Nelson, 1987), and $\mathrm{pH}$ (using de-ionized water) with a calibrated $\mathrm{pH}$ meter.

Bone (bone collagen) and cereal-grain samples were subject to radiocarbon (AMS) assay at the University of Toronto (TO) and the Scottish Universities Environmental Research Centre - NSF University of Arizona AMS Facility (AA) (Barrett et al., 2000b; Simpson et al., 2000). Error ranges quoted are calibrated at $2 \sigma$ using the atmospheric curve of Stuiver et al. (1998).

\section{RESULTS AND DISCUSSION}

\section{Site Chronology}

Radiocarbon measurements are reported in Table I. The earliest age from Area G is A.D. 782-995 (context G037), and the interface between the lower (with mammal bone) and upper (with fish bone) blocks of this stratigraphy can be dated to A.D. 1004-1262 (context G020/G021). Radiocarbon measurement from the raised soil context overlying the farm mound (context G025) yielded an age of A.D. 1256-1400, indicating a later medieval origin for the raised soil. However, assays from profile TP2 yielded discrepant dates-1045-803 B.C. and A.D. 240-435. It is likely that the material on which these dates are based is residual, introduced with turf cut elsewhere and used to create the raised soil, or are associated with earlier phases of cultivation activity, indicating the long-term occupation of the area.

In Area A, the interface of the cultural deposits and subsoil has produced a date of A.D. 677-959 (context A026), possibly representing an underlying soil contemporary with the initial occupation of Area G. An initial date for the cultural deposits themselves is provided by a single assay on an articulated calf skeleton (recovered just outside column A; context E030), A.D. 996-1162, and a combined date on four cerealgrain samples of A.D. 1066-1241 (context A023; statistically equivalent results). Five assays from the uppermost context, A004, are not statistically equivalent at the $95 \%$ significance level as a result of bioturbation processes. However, samples AA-52326 and AA-52327 constitute a statistically equivalent set, yielding a combined date of A.D. 1223-1296. An assay of A.D. 1027-1276, on a cattle pelvis from a cellar feature dug into the cultural deposits (context D017), was expected to provide a TAQ (Terminus 
INTERPRETING THE VIKING AGE TO MEDIEVAL PERIOD

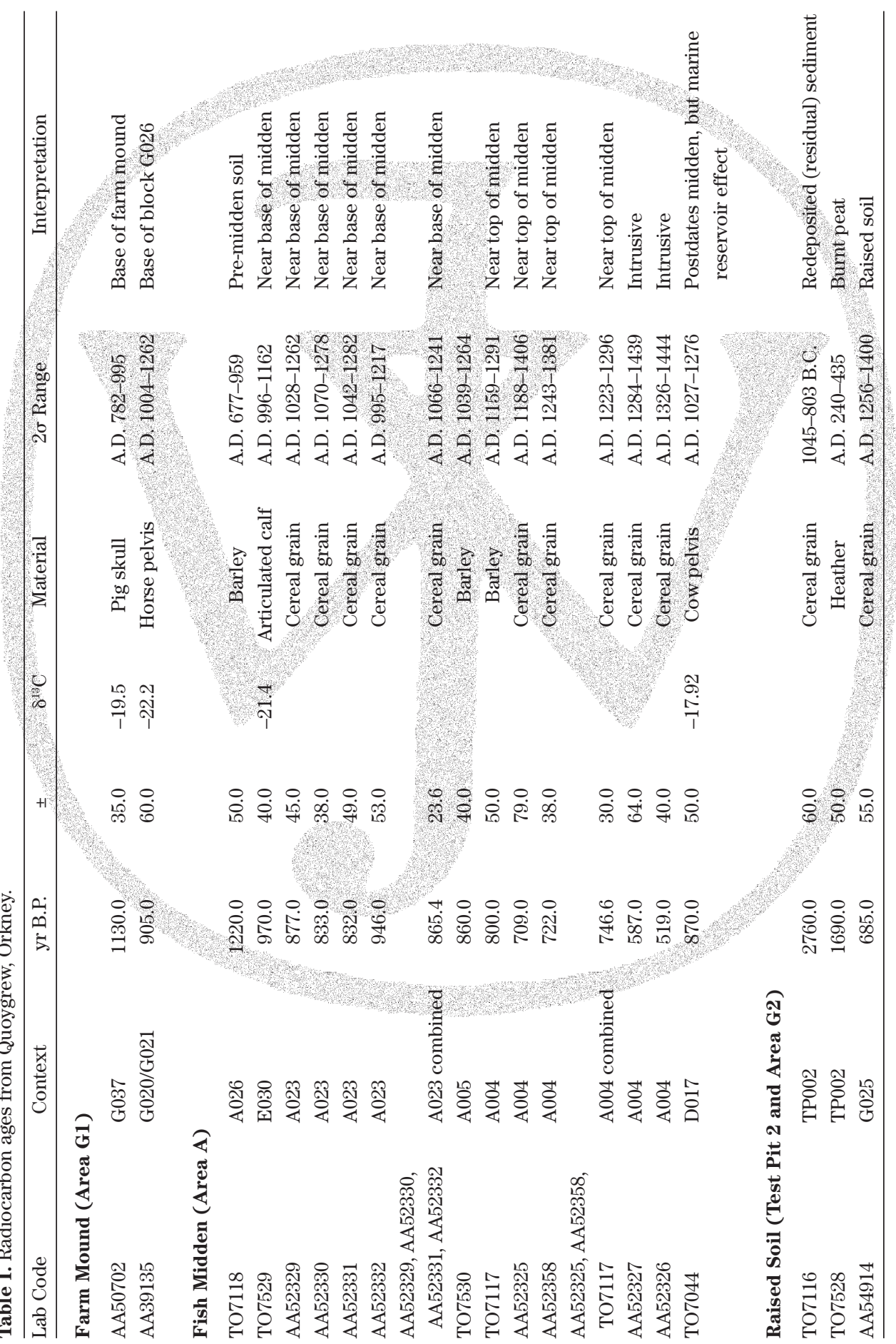


Ante Quem), but the $\delta^{13} \mathrm{C}$ value of $-17.92 \%$ implies that the animal in question was probably fed some fish waste or seaweed, making the assay appear older.

Our interpretation of the cultural sediment chronology at Quoygrew is that a full sequence of deposits from the Viking Age to the Medieval period is represented. The lower part of Area G represents Viking Age stratigraphy, possibly followed by an early period of Area A sediment accumulation. The upper stratigraphic zone of Area $\mathrm{G}$ and much of the Area A deposits can be considered contemporaneous Medievalperiod formations, while the material forming the raised soil, and overlying the Area $\mathrm{G}$ deposits, was formed later.

\section{Area A, Column A}

Results of bulk-soil analyses are presented in Table II and features observed in thin section are presented in Table III. Based on field observations (Figure 5), bulk-soil analyses, and systematic thin-section observations, the stratigraphy in Column A can be partitioned into three broad units based on sediment color, texture, structure, composition, and total phosphorus values. Microstructure, coarse mineral, and excremental pedofeature attributes allow the uppermost stratigraphic unit (A001-003) to be interpreted as a thickened and bioturbated midden and A-horizon soil material (Macphail, 1994), to which wind-blown shell sand was continuously added. Organic carbon and phosphorus values, and the frequency of phytoliths, organic matter, and the presence of dusty clay coatings in thin section, suggest that the lower, basal deposits (A026-027) belong to a weakly developed soil developed on boulder clay.

The major stratigraphic unit (A004-A025; thin sections 2-6; Figure 5) has a total thickness of $1 \mathrm{~m}$, with a sequence of cultural deposits that are variable in their microstratigraphy and with the frequent occurrence of fish-bone fragments. There are a number of consistent and significant features observed in thin sections from this unit. These include microcrystallitic b-fabrics (interpreted as fine-calcareous ash crystals), the presence of rubified fine-mineral material (Figure 6a), very few to few phytoliths and diatoms, and black, charred peaty flecks. The peaty features are identified as fragments of herbaceous and woody tissues in varying states of decomposition (slightly to very strongly decomposed, following FitzPatrick, 1993) and included monocot and dicot stems, roots, petioles, leaves/bracts, and inflorescences (Clapham and Fuller, personal communication). These observations allow the basic matrix of the deposits to be interpreted as peat ash. This interpretation is supported by reference to thin sections of Orcadian peat ash, although Area A sediments contain a higher percentage of sand and silt grains, either due to differences in the source of the peat or to a steady input of wind-blown quartz sand throughout the deposit's accumulation. Inclusions in the peat-ash residues include fish-bone fragments that are randomly oriented and distributed.

A number of post-depositional events affecting these cultural deposits can be observed in thin section. Traces of nonlaminated dusty clay coatings are found in thin sections $2-5$ (Figure $6 \mathrm{~b}$ ). These are isotropic or have a microcrystallitic birefringence, indicating that they are composed of fine-mineral material derived from peat ash that has translocated downwards through the strata (Slager and van der Wetering, 1977). 
INTERPRETING THE VIKING AGE TO MEDIEVAL PERIOD

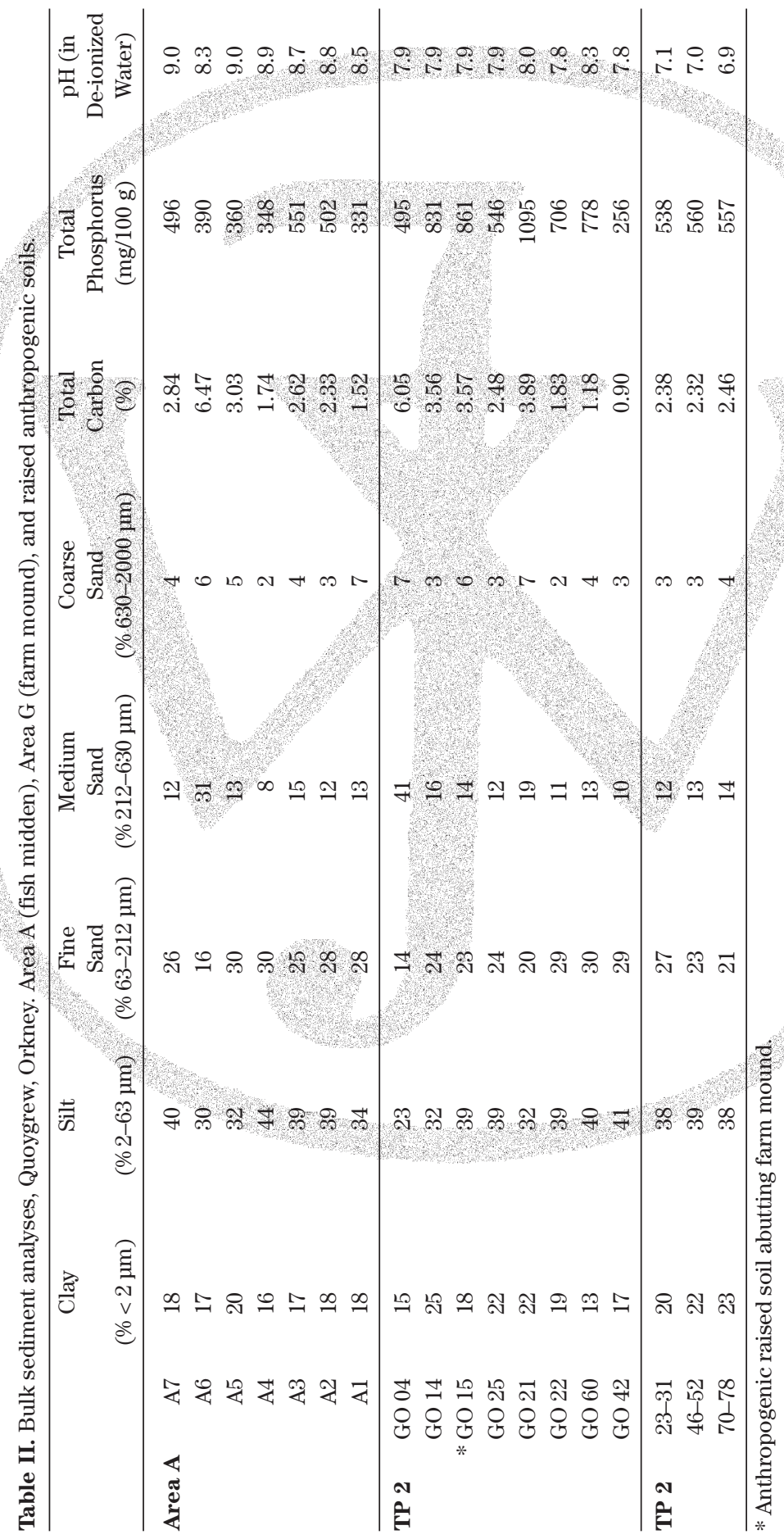




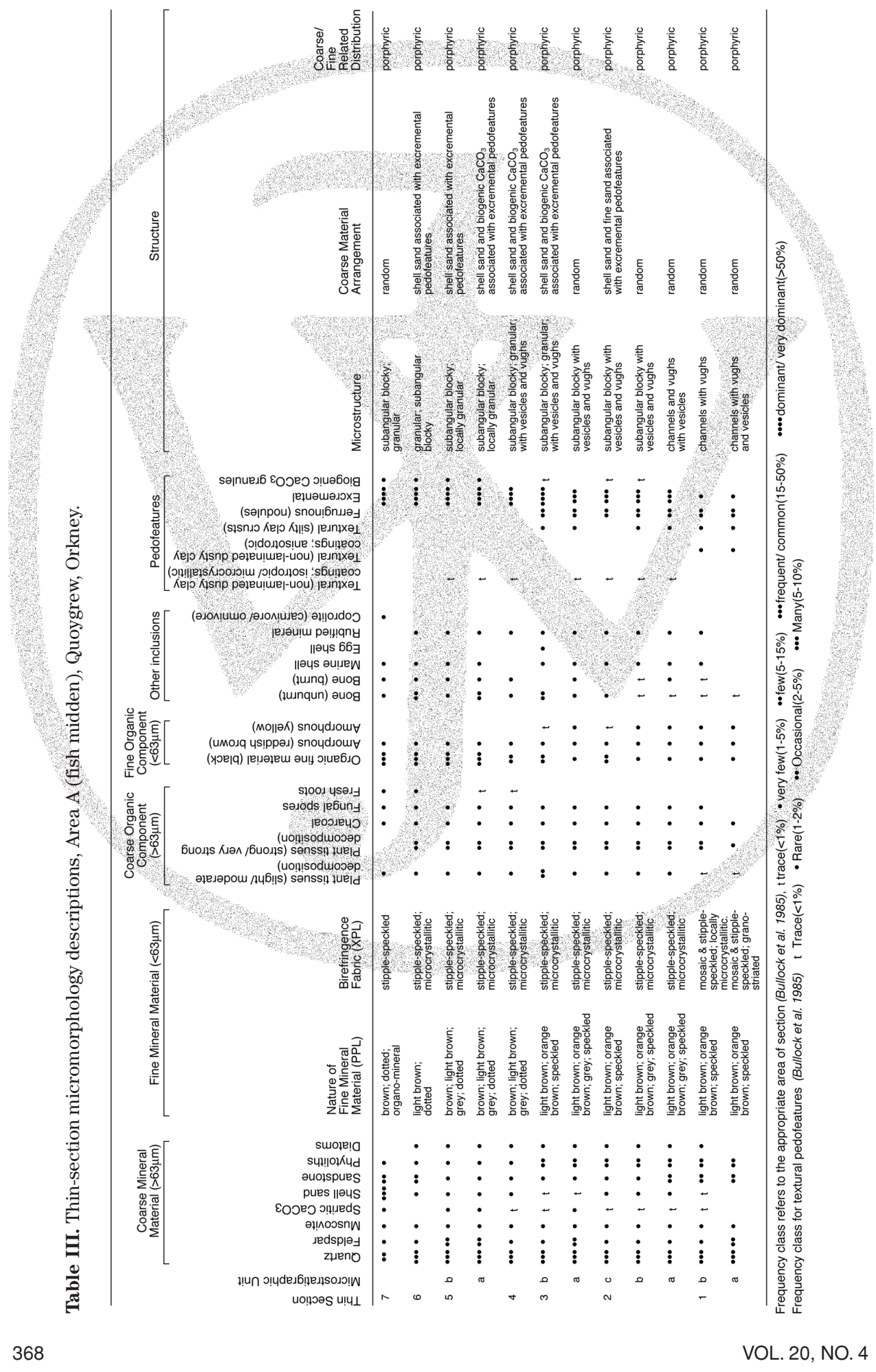




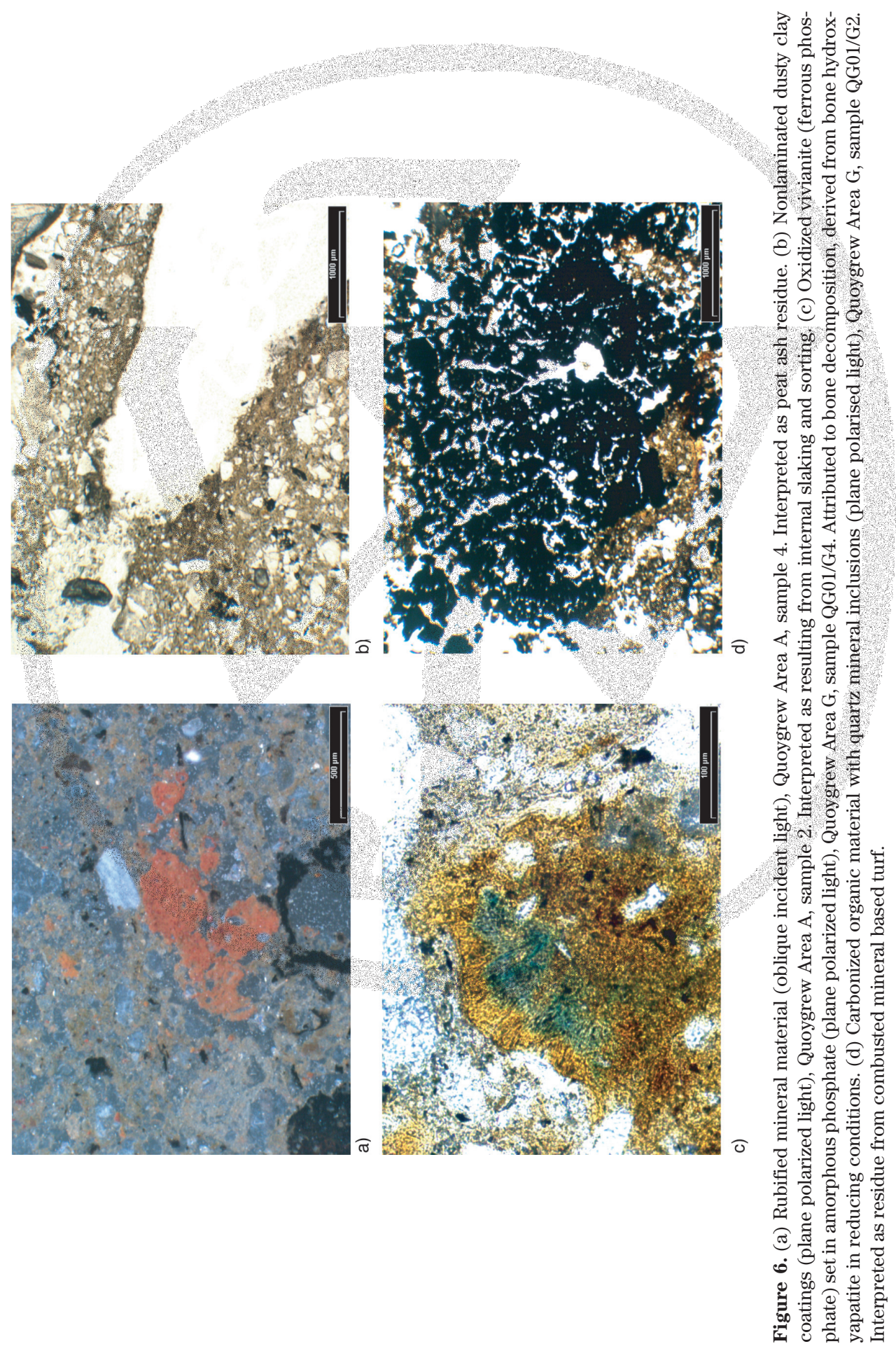


When considered with the subangular blocky and vesicular structure characterizing much of the deposits, it is reasonable to assume that the deposits underwent periodic wetting and drying (FitzPatrick, 1993). This is especially the case in the lower parts of the stratigraphy, from context A019 downwards, where a number of features combine to indicate that the deposits were exposed. Rare silty clay crusts are present, the thickest of which (ca. $250 \mathrm{\mu m}$ ) have a significantly elevated phytolith and organic component, most likely derived from peat ash, and may indicate an exposed surface. Other, finer crusts may have been formed and sealed over a shorter time period, or as a result of internal slaking and sorting (FitzPatrick, 1993). In addition, rare ferruginous nodules begin to be evident in context A019 and continue throughout the lower sediments, indicating that these layers were subjected to alternating wet and dry conditions. Although iron nodules and silty clay crusts were not observed in the upper parts of the stratigraphy, it is possible that this is due to their disruption by bioturbation, since the upper part of the stratigraphy has very abundant earthworm channels, mammilate excrement, granular excrement, and rare vermiforms. In the lower parts of the stratigraphy, where there is a significant decrease in the amount of faunal activity, fine crusts had a better chance of surviving. Even here, they are typically less than $1 \mathrm{~cm}$ in length.

Micromorphological analysis of the Area A deposits at Quoygrew indicates that much of the basic matrix is peat ash, within which fish bones and shells, observed in the field, were embedded, suggesting that this is a substantial fish-waste midden. It is likely that the peat ash was produced during the rendering of fish oils, in which fish livers are boiled in large pots (cf. McGregor, 1880; Cerón-Carrasco, 1994; Barrett et al., 1999). Steatite vessel sherds were common finds in the deposits, and cod-liver oil is known to have been produced and traded on a large seale in the North Atlantic region later in the Middle Ages, when detailed historical records first become available (e.g., Vollan, 1959; Fenton, 1978). The shell lenses in the stratigraphy are best interpreted as the remains of bait (Fenton, 1992). Preliminary zooarchaeological analysis of the fish bone from the deposits is consistent with the interpretation that dried cod and related species, which are known to have been widely traded in medieval Europe, were produced at Quoygrew (Colley, 1983; Barrett et al., 1999). The occurrence of nonlaminated dusty clay coatings, as well as silty clay crusts associated with phytoliths, indicates that there were relatively short periods of time when there was no deposition of cultural material and sediments were subject to surface processes, at least in the area of the mound considered. When these observations are considered in conjunction with the large extent and consistency of the deposits, it is best interpreted as a specialized fish-processing area with intermittent but regular activity. To our knowledge, Quoygrew represents the earliest dated example of such a fish-waste midden, and thus of the intensive exploitation of marine resources in Atlantic Scotland (cf. Barrett et al., 1999).

\section{Area G}

Table II contains results of bulk soil analyses, with features observed in thin section presented in Table IV. Cultural sediments are characterised throughout (excluding G025) by their similarity in coarse and fine mineral materials, and in their microstructural characteristics. These characteristics indicate similar background 
INTERPRETING THE VIKING AGE TO MEDIEVAL PERIOD

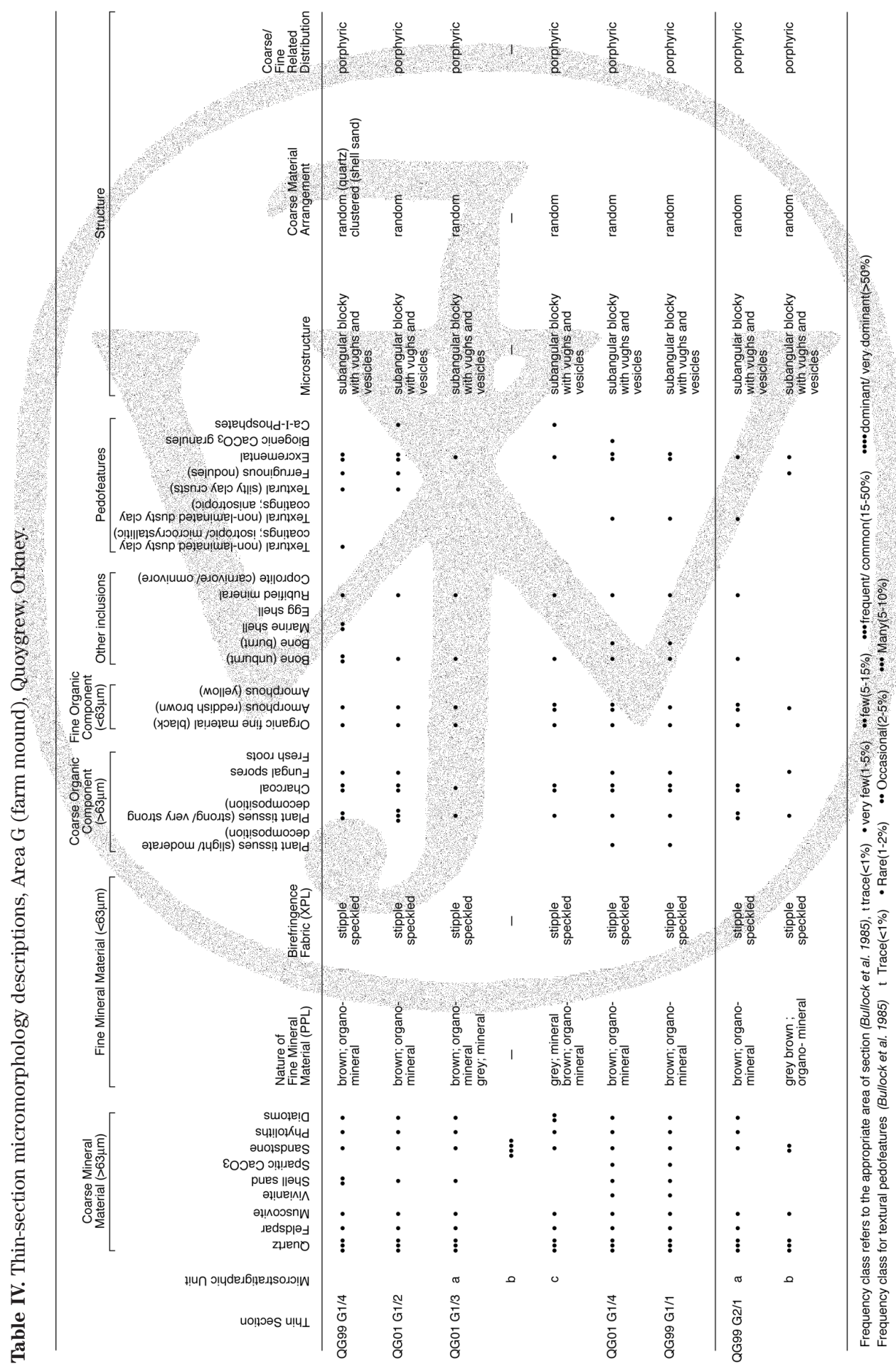


processes of accumulation, dominated by sediment input of mineral material derived from podsolic soils developed on Old Red Sandstones, with calcareous wind-blown sand a minor component. The sediments have also been reorganized, to a limited extent, by biological activity.

The most significant stratigraphic distinction evident in the field is between an upper zone (Block G026), in which the osteological material is dominated by fish bone, and a lower zone, where mammal bone is predominant. In thin section, the upper and lower parts of the stratigraphy are separated by a weathered, $5 \times 1 \mathrm{~cm}$ sandstone (Table IV; QG01 G1/3b). This field-based distinction between upper and lower sections of the farm-mound stratigraphy is confirmed in thin section by the relative frequencies of fish and mammal bone, and features derived from bone. Micromorphologic observations indicate that both types of bone material are found in each section of the stratigraphy, and that a greater proportion of bone is found in the uppermost part of the stratigraphy. Burnt bone is also evident, but only in the lower part of the stratigraphy. However, two types of crystalline bone decomposition products are evident in thin section: (1) vivianite (ferrous phosphate, blue when oxidized; Figure 6c), found in the lower part of the stratigraphy, and (2) yellow, weakly anisotropic crystals (calcium-iron-phosphate compounds), which are associated with coarse and fine black organic material, occurring in the upper part of the stratigraphy. In archaeological contexts, the calcium-iron-phosphate features are thought to originate by the release of $\mathrm{P}$ and $\mathrm{Ca}$ from bone hydroxy-apatite into ionic solution with subsequent re-adsorption onto active ferric hydroxides. Such features are often associated with fish waste (Simpson et al., 2000). The occurrence of vivianite in the lower section of the stratigraphy can also be attributed to bone decomposition, but in wet sediment, since the formation of vivianite requires reducing conditions. Both of these features indicate that bone decomposition within these sediments may have been significant, and that caution is required when drawing conclusions on economic activity from conventionally recovered bone material.

Other features with the potential to provide detail on variation in the anthropogenic processes contributing to sediment accumulation are similar in their frequency and organization. There is consistent occurrence of carbonized (black) and uncarbonized (reddish-brown) coarse organic material, both of which have varying amounts of mineral inclusions (Figure 6d). Related to the occurrence of these features are very few diatoms and phytoliths, some of which are clustered in discrete areas. There are also consistent, infrequent occurrences of rubified (reddened) mineral material evident in oblique incident light. Together, these observations suggest the introduction of peat (limited mineral inclusions and diatoms) and turf (higher frequency of mineral inclusions and phytoliths) to the stratigraphy. Both peat and turf could have been used for construction material (e.g., roofing material), as bedding in byres, or as fuel. A subtle distinction can be made between the upper part of the stratigraphy and the lower part, where there is a more frequent occurrence of amorphous (reddish-brown) fine organic materials and a smaller size of carbonized materials, although the frequency is similar to that in the upper part.

Textural pedofeatures up to $50 \mu \mathrm{m}$ in thickness are infrequently represented in these thin-section samples as nonlaminated isotropic and anisotropic dusty clay 
coatings and as silty clay crusts. As these features are of small size and lack microlamination, they can be interpreted as resulting from short-term movement from unvegetated surfaces prior to the surface being buried by further deposition. Given their limited and rare occurrence in the stratigraphy, it is likely that these exposed surfaces were of very limited duration in the formation of the farm mound, with new sedimentary material being continuously deposited.

In Area $\mathrm{G}$, the deposits are consistent with the persistent deposition of a range of domestic-occupation debris, including turf-construction materials, animal bedding material, peat and turf-fuel residues, deposited throughout cultural sediment accumulation. Fish debris appears to be more prevalent in the upper part of the stratigraphy, although caution is required with this interpretation, given the micromorphological evidence of bone decomposition and recrystallization. Irrespective of how bone materials are interpreted, the deposits are consistent with the interpretation as a farm mound and are in clear contrast to the Area A, fish-waste midden, deposits.

\section{Raised Soils}

Raised soils at the Quoygrew site form two discrete areas. The larger area (ca. 1.5 ha) reaches a maximum thickness of over $60 \mathrm{~cm}$ in the soil stratigraphy and abuts the farm mound (Area G) to the south and east, while a smaller area (ca. 0.25 ha) reaches a maximum thickness of over $20 \mathrm{~cm}$ and is to the north. These soils are overlain by wind-blown calcareous sandy loam and loamy sand (Table V). Enhanced total phosphorus values of between 538 and $560 \mathrm{mg} / 100 \mathrm{~g}$ are comparable to values found in anthropogenic soils elsewhere in Orkney (Simpson, 1997), supporting the interpretation of the raised soil as an amended anthropogenic soil (Table II) and their classification as plaggic anthrosols (World Reference Base, 1998) or plaggenthrepts (Soil Survey Staff, 1998). Field profiles and thin-section micromorphological descriptions (Tables V and VI) show iron mottling and occasional to many iron nodules, indicating that the anthropogenic soils were formed on imperfectly to poorly drained soils. Given the abrupt boundary between the deep anthropogenic soils and the underlying subsoil, it is likely that the original soils were also shallow. From the perspective of arable cultivation, such soils would have had limited rooting depth and waterlogging, making them poor-quality arable land. Indeed, given the availability of lighter textured, freely drained machair soils just south of the site, the original soils were unlikely to have been a first choice for cultivation.

In thin section, the anthropogenic soils are uniformly characterized by a range of features that directly and indirectly indicate their mode of formation (Table VI). Furthermore, the single thin-section sample taken from the interface between the farm mound and raised anthropogenic soil exhibits characteristics similar to those of the raised soil, rather than of the farm mound (Table IV). The consistent occurrence of phytoliths and the high mineral content of the soils (including quartz, feldspar, and muscovite) suggests that grassy turves were a primary element of anthropogenic soil formation. Furthermore, the frequency of fine, well-decomposed organic material suggests that the addition of organic matter was also integral to the formation process. This is supported by the channel and chamber microstructures and the 
Table V. Field descriptions of soil stratigraphies with raised anthropogenic soils.

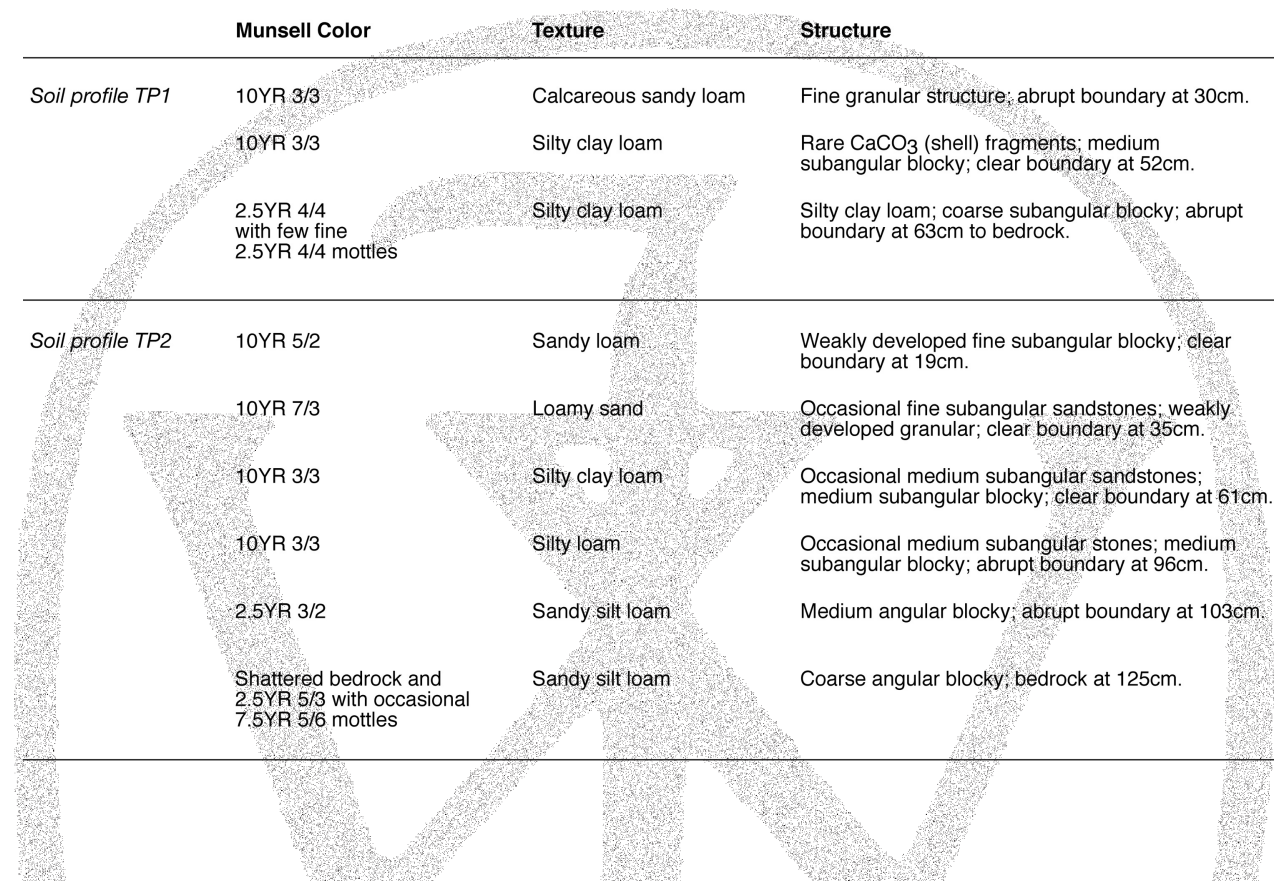

excremental pedofeatures, from which it is possible to infer substantial soil microand mesoorganism activity as a result of organic amendments. Based on the high phosphorus values, it is likely that the organic component was increased by the addition of animal manures. The presence of rubified minerals also suggests that other domestic wastes, such as turf-ash residues, may also have been added.

Textural pedofeatures evident in thin section include clay coatings and silty clay infillings. Dusty, nonlaminated clay coatings are prevalent in the larger area (profile TP002), while silty clay textural pedofeatures are more prevalent in the smaller area (profile TP001). A spade mark preserved by infilling with wind-blown sand suggests that the smaller area of anthropogenic soil north of the farm mound may have been spaded as a garden or to create the cultivation ridges indicated by a resistivity survey (cf. Halliday, 1993; Carter, 1998). While textural pedofeatures may be formed as a result of a number of processes, a major contributory factor is structural breakup of surface-soil peds by cultivation implements, slaking, and mobilization of water-saturated soil, followed by the deposition of clay against a barrier or when the soil dried out (Jongerius, 1970; Macphail et al., 1987). The textural pedofeatures present in these soils may thus be interpreted as an indicator of cultivation activity. Similar pedofeatures have been identified in historical ethnographic cultivation contexts in Papa Stour, Shetland (Adderley et al., in preparation<zaq;2>).

The micromorphology of the raised soils at Quogrew is virtually identical to that of anthropogenic soils created over extensive areas of Orkney and parts of Shetland, which have been tentatively dated to the 12th or 13th centuries A.D., with formation continuing through to the late 1800 s A.D. These soils were created by the stripping of turf from the hill-land areas, using it as bedding in byres, and 


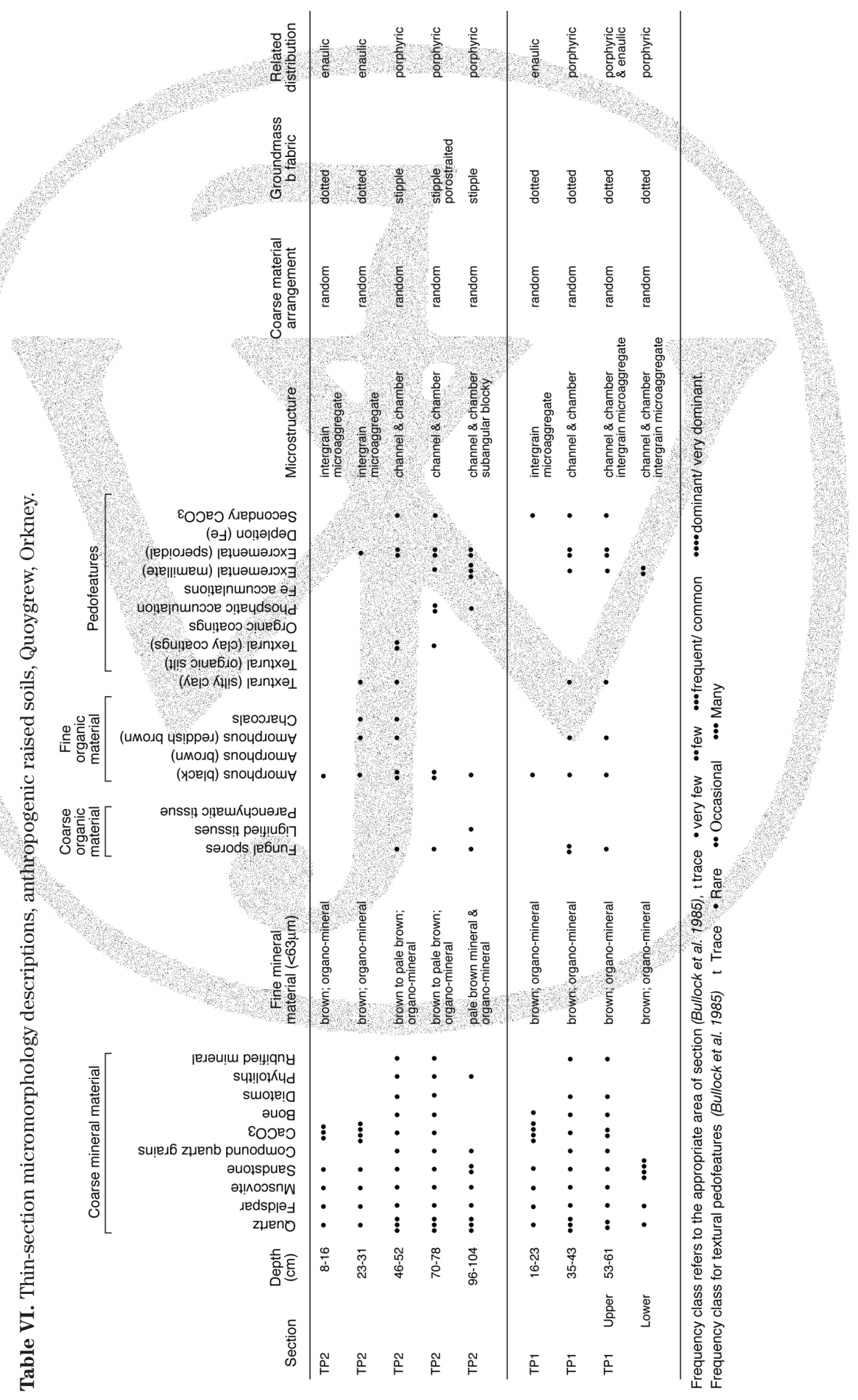


composting it with ruminant and pig manure and seaweed prior to deposition on continuously and intensively cultivated areas (Simpson, 1993, 1997; Davidson and Carter, 1998; Simpson et al., 1999). The development of such deep soils, therefore, requires careful integration of animal and arable husbandry and indicates a wellorganized agricultural community with well-defined land-use structures. The quality of these soils allowed substantial increases in cereal productivity (barley in particular) and permitted the production of surplus grain for trade (Adderley et al., 2000; Simpson et al., 2002).

\section{CONCLUSIONS}

The integration of emerging chronological frameworks and cultural sediment analyses at the Quoygrew site suggests a range of domestic debris accumulations, commencing during the Viking Age and continuing into the Medieval period, to form a farm mound (Area G). A discrete area of the site developed as a depositional zone for waste products from specialised marine-resource processing (Area A), commencing ca. A.D. 966-1162 and continuing until ca. A.D. 1223-1296, although possibly as late as A.D. 1444, as Quoygrew became more economically diverse. Arable land improvement, probably associated with the intensification of arable agriculture, is considered to be a later innovation at the site, commencing ca. A.D. 1256-1400, perhaps 250 years later than the intensification of marine-resource exploitation,

It is clear that the intensification of different sectors of the transition economy did not develop at the same time or at the same rate, and when set in a broader North Atlantic context, we suggest that intensive fishing advanced earlier and more quickly because of its large, early market in continental Europe (Barrett et al., 2000a), whereas cereal (barley) was produced in Orkney for a considerably smaller market in other North Atlantic Norse polities, including Iceland and Norway (IslendingaIsleninga Saga, McGrew, 1970; Bandamanna Saga, Porter, 1994). Furthermore, we also suggest that marine exploitation and the subsequent arable intensification developed as part of a long-term trend towards increasing rural productivity. Similar conclusions have been drawn from the study of Medieval commercial fiskevaer communities in Vesterålen, northern Norway, where the intensification of fishing activity took place in an area that already had a longstanding tradition of specialized fishing activity, dating from the early centuries of the 1st millennium A.D. (Simpson et al., 2000). In Orkney, it is also emerging that fishing was already important in the Viking Age, and became even more so during the transition to the Medieval period (Barrett et al., 2001). The intensification of arable activity in northern Scotland through the creation of raised soils may also have an earlier origin, as indicated by the ongoing excavations and paleolandscape analyses at the Iron Age broch settlement of Scatness in Shetland (ca. 200 B.C.-400 A.D.; Simpson et al., 1998). At a local level, economic transition and intensification were dependent upon earlier settlement and on the wide-ranging and complex cultural knowledge that local people had of their local environment. Future analyses focusing on testing and refining these insights on fishing and agricultural intensification are now required by considering further North Atlantic sites where a range of cultural sediments can be identified. 
This work forms part of the Viking Age Transitions Project, funded by Historic Scotland, Orkney Islands Council, the Social Sciences and Humanities Research Council of Canada, the Society for Mediaeval Archaeology, the University of York, Orkney Archaeological Trust, and the University of Glasgow. Research support was also provided to IAS by the Faculty of Environmental Sciences, University of Guelph, Canada. K.B.M. gratefully acknowledges the support of the Social Sciences and Humanities Research Council of Canada, the Overseas Research Students Awards Scheme in the United Kingdom, the Cambridge Commonwealth Trust, and Newnham College, Cambridge. George MacLeod (University of Stirling) manufactured the thin sections. Plant remains in thin section were identified with the assistance of Alan Clapham (University of Durham) and Dorian Fuller (Institute of Archaeology, University College London). Plant remains for radiocarbon dating were identified by Sandra Poaps (University of Toronto) and Jacqui Huntley (University of Durham). Derek Hall (Scottish Urban Archaeological Trust) kindly provided information regarding the artefact assemblages. Bill Jamieson (University of Stirling) and Jerad Zimmermann and Toby Simpson (both University of York) produced the figures and tables. Interpretations of peat ash and burnt bone benefited from access to the thin section reference collection at the Ancient Monuments Laboratory at English Heritage.

\section{REFERENCES}

Adderley, W.P., Simpson, I.A., Lockheart, M.J., Evershed, R.P., \& Davidson, D.A. (2000). Modeling traditional manuring practice: Soil organic matter sustainability of an early Shetland community? Human Ecology, 28, 415-431.

Andersson, H. (2002). Centre-periphery, world systems and medieval archaeology. In G. Helmig, B. Scholkmann, \& M. Untermann (Eds.), Centre, region, periphery: Medieval Europe. Basel 2002 (Volume 1, pp. 23-34). Hertingen, Germany: Verlag Dr. G. Wesselkamp.

Barrett, J.H. (1997). Fish trade in Norse Orkney and Caithness: A zooarchaeological approach. Antiquity, 71, 616-638.

Barrett, J.H., Nicholson, R.A. \& Cerón-Carrasco, R. (1999). Archaeo-ichthyological evidence for longterm socioeconomic trends in northern Scotland: 3500 B.C. to A.D. 1500. Journal of Archaeological Science, 26, 353-388.

Barrett, J.H., Beukens, R., Simpson, I.A., Ashmore, P., Poaps, S., \& Huntley, J. (2000a). What was the Viking Age and when did it happen? A view from Orkney. Norwegian Archaeological Review, 33, 1-39.

Barrett, J.H., Beukens, R.P., \& Brothwell, D.R. (2000b). Radiocarbon dating and marine reservoir correction of Viking Age Christian burials from Orkney. Antiquity, 74, 537-543.

Barrett, J.H, Beukens, R.P., \& Nicholson, R.A. (2001). Diet and ethnicity during the Viking colonisation of northern Scotland: Evidence from fish bones and stable carbon isotopes. Antiquity, 75, 145-154.

Bullock, P., Federoff, N., Jongerius, A., Stoops, G., Tursina, T., \& Babel, U. (1985). Handbook for soil thin section description, Wolverhampton, UK: Waine.

Carter, S. (1998). Palaeopedology. In R.P.J. McCullough \& R. Tipping (Eds.), The Lairg project 1988-1996: The evolution of an archaeological landseape in Northern Seotland (pp. 150-161). Edinburgh: Scottish Trust for Archaeological Research.

Cerón-Carrasco, R. (1994). The investigation of fish remains from an Orkney farm mound. In W. Van Neer (Ed.), Fish exploitation in the past: Proceedings of the 7th Meeting of the ICAZ Fish Remains Working Group (pp. 207-210). Tervuren, Belgium: Musee Royal de l'Afrique Centrale.

Clouston, J.S. (1922). The Orkney pennylands. Scottish Historical Review, 20, 19-27.

Colley, S.M. (1983). The role of fish bone studies in economic archaeology: With special reference to the Orkney Isles. Unpublished doctoral dissertation, University of Southampton, Southampton, U.K.

Courty, M.A., Goldberg, P., \& Macphail, R.I. (1989). Soils and micromorphology in archaeology. Cambridge: Cambridge University Press.

Davidson, D.A., Harkness, D.D., \& Simpson, I.A. (1986). The formation of farm mounds on the island of Sanday, Orkney. Geoarchaeology, 1, 45-60.

Davidson, D.A., \& Carter, S.P. (1998). Micromorphological evidence of past agricultural practices in cultivated soils: The impact of a traditional agricultural system on soils in Papa Stour, Shetland. Journal of Archaeological Science, 25, 827-838. 
Davidson, D.A. \& Simpson, I.A. (2001). Archaeology and soil micromorphology. In D.R. Brothwell \& A.M. Pollard (Eds.), Handbook of archaeological sciences (pp. 167-177). Chichester: Wiley.

Fenton, A. (1978). The Northern Isles: Orkney and Shetland. Edimburgh: John Donald.

Fenton, A. (1992). Shellfish as bait: The interface between domestic and commercial fishing. In T.C. Smout (Ed.), Scotland and the sea (pp. 137-153). Edinburgh: John Donald.

FitzPatrick, E.A. (1993). Soil microscopy and micromorphology. Chichester: Wiley.

Halliday, S.P. (1993). Marginal agriculture in Seotland. In T.C. Smout (Ed.), Scotland sinee prehistory: Natural change and human impact (pp. 64-78). Aberdeen: Scottish Cultural Press.

Helle, K. (1993). Norway, 800-1200. In A. Faulkes \& R. Perkins (Eds.), Viking revaluations (pp. 1-14). London: Viking Society for Northern Research.

Jongerius, A. (1970). Some morphological aspects of regrouping phenomena in Dutch soils. Geoderma, 4, 311-331.

Macphail, R.I. (1994). The reworking of urban stratigraphy by human and natural processes. In A.R. Hall \& H.K. Kenward (Eds.), Urban-rural connexions: Perspectives from environmental archaeology (pp. 13-43). Oxford: Oxbow.

Macphail, R.I. Romans, J.C.C., \& Robertson, L. (1987). The application of micromorphology to the understanding of Holocene soil development in the British Isles with special reference to early cultivation. In N. Federoff, L.M. Bresson, \& M.A. Courty (Eds.), Soil micromorphology (pp. 647-656). Plaiser $<$ zad, 3> : AFES.

Marwick, H. (1952). Orkney farm names. Kirkwall, UK: W.R. Mackintosh.

McGregor, A. (1880). Notes on some old customs in the Island of Sky. Proceedings of the Society of Antiquaries of Scotland, 14, 143-148.

McGrew, J. (1970; translation). Sturlunga saga. New York: Twayne and the American Scandinavian Foundation.

Miller, J.D. (1866). The estate of Trenabie, Westray: The property of David Balfour Esq. of Balfour. Unpublished manuscript held in Westray Heritage Centre.

Nelson, N.S. (1987). An acid-persulfate digestion procedure for determination of phosphorus in sediments. Communications in Soil Science and Plant Analysis, 18, 359-369.

Porter, J. (1994; translation). Bandamanna saga. Felinbach, UK: Llanerch.

Simpson, I.A. (1993). The chronology of anthropogenic soil formation in Orkney. Scottish Geographical Magazine, 109, 4-11.

Simpson, I.A. (1997). Relict properties of anthropogenic deep top soils as indicators of infield management in Marwick, West Mainland, Orkney. Journal of Archaeological Science, 24, 365-380.

Simpson, I.A., \& Barrett, J.H. (1996). Interpretation of midden formation processes at Robert's Haven, Caithness, Scotland using thin section micromorphology. Journal of Archaeological Science, 23, $543-556$.

Simpson, I.A., Dockrill, S.J., \& Lancaster, S.J. (1998). Making arable soils: Anthropogenic soil formation in a multi-period landscape. In R.A. Nicolson \& S.J. Dockrill (Eds.), Old Scatness Broch: Retrospect and prospect (pp. 111-126). North Atlantic Biocultural Organisation, Monograph No. 2. Bradford, U.K., University of Bradford.

Simpson, I.A., van Bergen, P.F., Perrett, V., Elhmmalli, M.M., Roberts, D.J., \& Evershed, R.P. (1999). Lipid biomarkers of manuring practice in relict anthropogenic soils. The Holocene, 9, 223-229.

Simpson, I.A., Perdikaris, S., Cook, G., Campbell, J.L., \& Teesdale, W.J. (2000). Cultural sediment analyses and transitions in early fishing activity at Langenesværet, Vesterålen, northern Norway. Geoarchaeology, 15, 743-763.

Simpson, I.A., Adderley, W.P., Gudmundsson, G., Hallsdóttir, M., Sigurgeirsson, M.Á., \& Snæsdóttir, M. (2002). Soil limitations to agrarian land production in pre-modern Iceland. Human Ecology, 30, 423-443.

Slager, S., \& van der Wetering, H.T.J. (1977). Soil formation in archaeological pits and adjacent loess soils in southern Germany. Journal of Archaeological Science, 4, 259-267.

Soil Survey Staff. (1998). Keys to soil taxonomy. Blacksburg, VA: Pocahontas Press.

Stoops, G. (2003). Guidelines for the analysis and description of soil and regolith thin sections. Madison, WI: Soil Science Society of America.

Stuiver, M., Reimer, P.J., Bard, E., Beck, J.W., Burr, G.S., Hughen, K.A., Kromer, B., McCormac, G., van der Plicht, J., \& Spurk, M. (1998). INTCAL89 radiocarbon age calibration 24,000-0 cal B.P. Radiocarbon, 40, 1041-1083. 
Thomson, W.P.L. (1987). History of Orkney. Edinburgh: Mercat Press.

Thomson, W.P.L. (1995). Orkney farm-names: A re-assessment of their chronology. In B.E. Crawford (Ed.), Scandinavian settlement in Northern Britain (pp. 42-63). London: Leicester University Press. Urbanczyk, P. (1992). Medieval Arctic Norway. Warsaw: Institute of Archaeology and Ethnology. Vollan, O. (1959). Fisketilvirkning. Kulturhistorisk Leksikon for Nordisk. Middelalder, 4, 343-344. World Reference Base. (1998). World reference base for soil resources. Rome: FAO-ISSS-ISRIC.

Zimmermann, J. (2001). GIS and archaeological deposit modelling: A case study from Westray, Orkney. Unpublished master's thesis, University of York, York, U.K.

Received March 28, 2002

Accepted for publication May 21, 2004

\section{QUERIES}

$<$ senote>>AQ1: Referee query: should there be a trademark for Calgon?

$<$ renote $>>A Q 2$. List in References?

rsenote $>$ AQ3: Please include country or state if in USA.

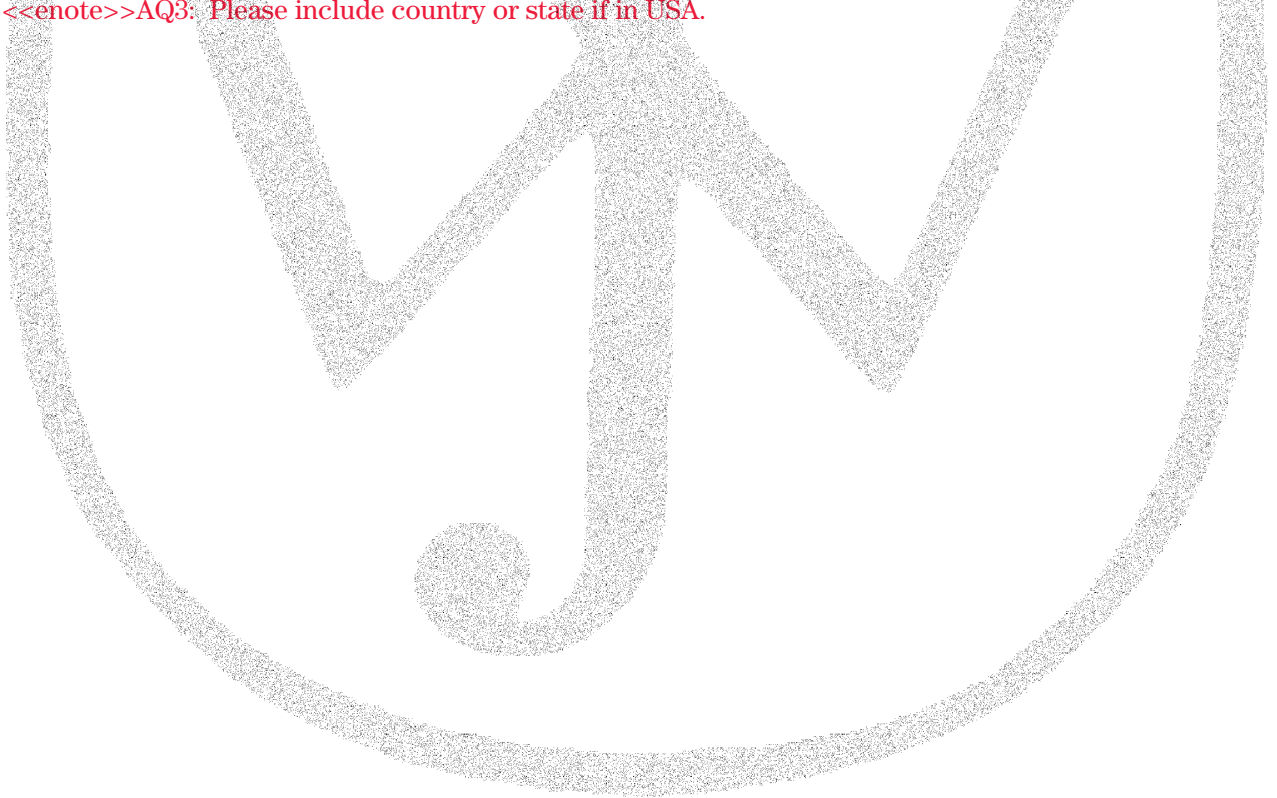

